\title{
HOMELAND SECURITY INTERNET SOURCES
}

\section{USEFUL SITES, PORTALS AND FORUMS}

\section{Homeland Security Home Page}

http://www.whitehouse.gov/homeland/

A federal agency whose primary mission is to help prevent, protect against, and respond to acts of terrorism on United States soil.

\section{U.S. Department of Homeland Security}

http://www.dhs.gov/dhspublic/index.jsp

Governmental agency working on the prevention of terrorist attacks within the United States, reducing America's vulnerability to terrorism, and minimizing the damage from potential attacks and natural disasters. Includes articles, news and grants programs.

\section{Homeland Security Institute}

http://www.homelandsecurity.org/

The primary mission of the Homeland Security Institute is to assist the Department of Homeland Security (DHS) and its Operating Elements in addressing important homeland security issues, particularly those requiring scientific, technical, and analytical expertise. The institute provides extensive coverage on the issue and information on current events, a weekly newsletter, bibliography, virtual library, and links.

\section{Survivability/Vulnerability Information Analysis Center (SURVIAC)}

http://www.bahdayton.com/surviac/ 
SURVIAC is the U.S. DoD's institution for collecting, analyzing, and disseminating scientific and technical information related to all aspects of survivability and lethality for aircraft, ground vehicles, ships and spacecraft, to conventional homeland security threats including chemical, biological, directed energy, and non-lethal weapons.

\section{Homeland Security Advisory System}

http://www.nationalterroralert.com/overview.htm

This is the website of a Homeland Security advisory system and resources. It provides Homeland security guides for preparing against terror attacks and a free 300-pages homeland security manual.

\section{Air War College: Homeland Security, Homeland Defence, Domestic Preparedness}

http://www.au.af.mil/au/awc/awcgate/awc-hmld.htm

Links to mostly government and military websites related to homeland security, created for military members by the Air War College.

\section{Federal Commission for NBC-Protection (ComNBC): Facts on NBC threats}

http://www.komabc.ch/e/aktuell/index.htm

After the terror attacks in the US: Facts on the threat of nuclear, biological and chemical weapons (NBC weapons).

Commission of the European Communities: Reinforcing the Civil Protection Capacity of the European Union, European Commission, Brussels, Belgium http://europa.eu.int/eur-lex/en/com/cnc/2004/com2004_0200en01.pdf

A set of recommendations on Civil Protection to the European Parliament and the European Council, released on 25 March 2004 in light of a series of natural disasters in 2002 and 2003 and the recent terrorist bombings in Madrid.

\section{ON-LINE JOURNALS}

\section{Journal of Homeland Security}

http://www.homelandsecurity.org/journal/ 
The interdisciplinary, refereed Journal of Homeland Security is devoted to the discussion and analysis of issues related to the subject of Homeland Security. The Journal publishes feature articles, book reviews, commentaries and articles focusing on science and technology relevant to the field of homeland security.

\section{Journal of Homeland Security and Emergency Management}

http://www.bepress.com/jhsem/

This journal aims to provide new information and understanding of emergency management in the homeland security environment and hopes to foster a community of persons who share these interests. Its intent is to provide quality content in the new realm of homeland security and to discuss the relationships between emergency management (for natural, technological and industrial, and terrorism events) as currently understood and conducted and the new field of homeland security.

Journal's intent is to provide information and insights on homeland security and emergency management from a broad array of professions, including engineering; political science/public administration/ policy analysis; decision science; and health and medical.

\section{Homeland Security}

http://www.govexec.com/homeland/

This is a monthly publication for senior U.S. Government officials. It includes regularly updated features on management, homeland security, defense, outsourcing, procurement, and e-government.

\section{Homeland Security Weekly}

http://www.homelandsecurity.org/bulletin/current_bulletin.htm

This is a homeland security resource newsletter. It offers free online courses and books, utilities and links to federal and state agencies dealing with homeland security issues.

\section{Connections: The Quarterly Journal, Fall 2005}

http://www.pfpconsortium.org <Publications>

Special issue on homeland security, covering roles of the armed forces of seven countries both NATO members and neutral states. 


\section{McGraw-Hill's Homeland Security Magazine}

http://www.mcgraw-hillhomelandsecurity.com/

Journal's mission is to provide industry and government agencies with the information necessary to help protect the Homeland and develop commerce to enable them to achieve that goal. McGraw-Hill Homeland Security products and services include: The Homeland Security Supplement, The Homeland Security Summit and Exposition, The Homeland Security Channel on the Aviation Week Intelligence Network.

\section{Homeland Defense Journal}

http://www.homelanddefensejournal.com/

The journal is a monthly publication, featuring in-depth looks and analyses of homeland-related topics, the people leading this community and those that support them. Homeland Defense Journal and Homeland Defense Journal Online together seek to facilitate communication among all levels of government concerned with homeland security, covering the issues and the technology, solutions, policies, people, case studies and events affecting that community.

\section{CONFERENCES}

\section{Homeland Security Conference 2006}

http://www.afcea.org/events/homeland

The conference will be held on 22-23 February 2006 at Ronald Reagan International Trade Center, Washington, D.C.

\section{Fourth Annual Homeland Security Conference}

http://www.nmhsconference.org/

The 2005 Fourth Annual Homeland Security Conference will take place in Albuquerque, New Mexico, November 16-18, 2005. Activities will include presentations, workshops, and demonstrations by homeland security and counterterrorism experts and displays by nationally recognized vendors.

\section{Technologies for Critical Incident Preparedness Conference \& Exposition 2005} http://www.regonline.com/eventinfo.asp?EventId=21494 
This conference offers an opportunity for first responders, business and industry, academia, and elected federal, state, local, and tribal stakeholders to network, exchange ideas, and address common critical incident technology and preparedness needs and solutions. It will be held from October 31, 2005 until November 02, 2005 in San Diego, CA.

\section{Corporate Security, Business Continuity and Crisis Management Conference: Emerging Threats to the Corporation--Strategies to Detect, Deter and Defuse Crises}

http://www.conference-board.org/conferences/conference.cfm?id=980

At the conference, the private sector can find ways to protect companies against terrorism. This event will benefit senior executives, government officials, policy experts, and other thought leaders who want to examine strategies to limit risk, control damage, maintain critical operations, and effect recovery. It will be held at Westin New York at Times Square, New York, NY; November 17-18, 2005.

\section{$5^{\text {th }}$ Annual Critical Infrastructure Resilience \& Infrastructure Security for the Built Environment Congress \& Expo}

http://www.protectinfrastructure.com/

This event will bring together government and industry officials from around the world to discuss and formulate solutions to protect the homeland. Issues such as physical security, cyber-security, standards, interoperability, biometrics, threat and vulnerability assessments, research and development efforts, and first responder requirements will be discussed. 